UDC 336.532

DOI: $10.17721 / 2415-881 \times .2019 .83 .86-92$

\author{
Anatolij Bereza \\ Doctor of Political Sciences (Kiev, Ukraine) \\ https://orcid.org/0000-0003-1611-0274 \\ e-mail: avbereza@ukr.net
}

\title{
EVOLUTION AND INTITUTIONAL SUPPORT OF THE EU REGULATORY POLICY
}

\begin{abstract}
The conditions of transition of the EU bodies as a regulatory state to the policy of deregulation, which has taken the form of «smart regulation» and its specific are considered. Later the European Commission has renewed the concept of «better regulation» which main tasks are: the effective coordination and development of cooperation between Member States, as well as the implementation of relevant structural reforms; increasing the efficiency of the authorities of both the European Union and the Member States, their ability to respond to current challenges; ensuring greater transparency in the adoption of regulatory acts.

The need of creation appropriate institutions capable to implement regulatory policy and monitor its implementation has been fully recognized relatively recently. Their main task is to oversee, coordinate, challenge issues and provide advice to regulatory authorities, facilitate legislative reforms, improve the quality of the regulatory process and achieve certain benefits. Among the possible negative consequences of the activities of such bodies are: a decrease in regulatory quality in the infrastructure sector in the long run; sectoral principle of creation, which impedes convergence between sectors and may lead to fragmentation of public policy. These risks can be minimized by clearly defining the role of regulators and strengthening their accountability mechanisms.

In view of the proclaimed course on European integration, Ukraine should adapt its regulatory policy in line with current EU approaches. Also, EU experience has shown the need for appropriate institutional support for policies that should focus on the earliest possible stages of the legislative process: to publish the intentions of public authorities on changes in legislation (road maps) and to carefully monitor the compliance of existing legislation with the needs of society.
\end{abstract}

Key words: regulatory state; regulatory policy; transparency; European integration; nonelected bodies 


\title{
Береза Анатолій Валентинович
}

\author{
Доктор політичних наук ( м. Київ, Україна) \\ https://orcid.org/0000-0003-1611-0274 \\ e-mail: avbereza@ukr.net
}

\section{ЕВОЛЮЦІЯ ТАІНСТИТУЦІЙНЕ ЗАБЕЗПЕЧЕННЯ РЕГУЛЯТОРНОЇ ПОЛІТИКИ ЄВРОСОЮзУ}

\begin{abstract}
Резюме
Розглянуто передумови переходу органів Євросоюзу як регуляторної держави до політики дерегуляції, яка набула форми «розумного регулювання», а сьогодні реалізується концепція «кращого регулювання». Ї̈̈ основні завдання: ефективна координація і розвиток співробітництва між країнами-членами, а також реалізації супутніх структурних реформ; підвищення ефективності діяльності органів влади як Євросоюзу, так і держав-членів, їх здатності реагувати на сучасні виклики; забезпечення більшої прозорості у процесі прийняття нормативноправових актів.

Необхідність створення відповідних інститутів, які б були спроможні реалізувати регуляторну політику та слідкувати за її виконанням, повною мірою була усвідомлена відносно недавно. Серед можливих негативних наслідків діяльності таких органів: зниження у довгостроковій перспективі регуляторної якості в інфраструктурних секторах; секторальний принцип створення; що утруднює конвергенцію між секторами і може призвести до фрагментації державної політики. Мінімізувати ці ризики можна шляхом чіткого визначення ролі регуляторних органів та посилення механізмів їх підзвітності.
\end{abstract}

Ключові слова: регуляторна держава; регуляторна політика; прозорість; євроінтеграція; невиборні органи

\section{Bcmyn}

Регуляторна політика є невіддільною складовою сучасної держави, яка намагається захистити своїх громадян та розв'язати проблеми, які виходять за рамки ії компетенції (глобальне потепління, міжнародна міграція, глобальні економічні кризи тощо). Це зумовило необхідність удосконалення нормативно-правового втручання держави в суспільні відносини, що сприяло появі нового типу держави. У результаті в 1980-х роках з'явилися ознаки формування регуляторної держави на Європейському континенті. Відомий дослідник Дж. Маджоне так пояснив появу нового типу держави: «Приватизація та дерегулювання мають створити умови для появи регуляторної держави, що прийде на зміну диригентській державі минулого» [1, p. 77]. Ïї особливістю $є$ опора на регулювання, а не на державну власність, планове чи централізоване управління.

\section{Методи дослідження}

Проблематика регуляторної політики досить грунтовно досліджується економістами (з точки зору іiі впливу на економічний сектор) та юристами, які зосереджуються радше на юри- 
дичній техніці. Лише відносно недавно, починаючи з кінця ХХ ст. регуляторна політика почала розглядатися зарубіжними політологами у контексті формування нового виду держави - регуляторної, яка до певної міри протиставляється державі загального добробуту і сервісній державі. Для з'ясування суті регуляторної політики та іїі інституційного забезпечення використовувалися системний, структурно-функціональний, порівняльний методи.

\section{Результати}

У 2002 році фахівці Організації економічного співробітництва і розвитку (ОЕСР) виділили такі основні недоліки реформування регуляторної політики, зокрема:-брак або відсутність чітко сформульованих принципів якості регулювання, зокрема чіткого принципу співвідношення розмірів вигід і затрат, нерозуміння результатів, яких слід досягнути;-значні лакуни застосування політики, як щодо сфери національного регулювання, включеного у рамки його регулювання, щодо найбільш універсального включення субнаціонального регулювання, а також достатньої кількості винятків із загальної сфери політики;-брак чи відсутність консультацій з громадськістю в ході розробки регуляторної політики, що призводить до ії̈ низького рівня підтримки громадянами;- - брак чи відсутність інституційної і стратегічної підтримки політики з розподілом відповідальності, що є основним питанням для спротиву реформі;-нестача чи відсутність інструкцій щодо застосування політики, необхідних для міністерств та інших органів державної влади; - брак чи відсутність в органів, що відповідають за регуляторну політику, повноважень і механізмів їі примусового виконання;- - недостатня увага процесам моніторингу, оцінки і звітності, як через форму зворотного зв'язку, так і через підтримку і розширення кількості зацікавлених сторін [2, p. 4 ].

У свою чергу регуляторне законодавство ЄС постійно удосконалюється для досягнення наступних цілей:- ефективного координування і співробітництва між країнами-членами, а також реалізації супутніх структурних реформ (у сфері конкурентної політики, корпоративного управління та секторальних реформ); - підвищення ефективності діяльності органів влади як Євросоюзу, так і держав-членів, їх здатності реагувати на сучасні виклики, у тому числі через проведення адміністративної реформи; - більшої прозорості у процесі прийняття нормативноправових актів у тому числі через залучення всіх зацікавлених сторін та громадськості до їх обговорення.

Надмірне регулювання економічної діяльності на спільному європейського ринку зумовило необхідність зменшення кількості нормативно-правових актів та вироблення об' єктивних критеріїв оцінки їх ефективності і результативності. У результаті, у 2001 р. СС запровадив концепцію так званого «якісного регулювання». Пізніше вона була піддана критиці через низку недоліків:- брак чітко сформульованих принципів якісного регулювання, зокрема, чіткого принципу співвідношення розмірів вигоди і витрат, а також відсутність чіткого розуміння щодо результатів, які необхідно досягнути; - суттєві прогалини у сфері застосування політики, як щодо сфери національного регулювання, включеного в його у межі регулювання, так і міждержавного регулювання на рівні СС; - недостатня участь зацікавлених сторін, насамперед громадськості, у ході прийняття рішень, що зумовлює низький рівень довіри до регуляторної політики ЄС та посилює демократичний дефіцит Союзу-низький рівень інституційної і стратегічної підтримки політики із розподілом відповідальності;- - недостатня організація та управління 3 боку генеральних департаментів (міністерств) та інших урядових служб щодо застосування політики; - брак інститутів, відповідальних за політику реформ, а також повноважень і механізмів щодо її примусового виконання; - ігнорування важливості процесу моніторингу, оцінки та звітності, як за допомогою зворотного зв'язку, так і через підтримку і розширення кількості акторів, зацікавлених у реформі.

Намагаючись удосконалити регуляторну політику на початку XXI ст. Свропейська комісія запропонувала варіант «розумного регулювання», який намагався поєднати дерегулювання і ререгулювання. Серед запропонованих нею нововведень слід згадати такі поняття і кри- 
терії як:- «життєвий цикл» (усі етапи підготовки регуляторного акту: від розробки проекту до оцінки його фактичного впливу на відповідну сферу); - визначення економічних цілей (конкурентоспроможність, економічний ріст) за умови збереження якості життя або соціальної моделі; - акцентування уваги на результатах і участь заінтересованих сторін у процесі підготовки та апробації нових регуляторних актів.

В цілому, необхідність запровадження розумного регулювання в СС була викликана усвідомленням того, що належне регулювання може забезпечити: підвищення конкурентоспроможності; більшу відкритість ринку; поліпшення рівня життя; захист навколишнього середовища; більшу прозорість діяльності органів державної влади; підтримку правопорядку тощо.

Розумне регулювання базується на дванадцяти основних принципах, а саме: пропорційність, відповідальність, послідовність, прозорість, адресність, необхідність, субсидіарність (фінансове забезпечення), доступність, простота, результативність, економічна ефективність, своєчасність. Планувалося, що основними інструментами, за допомогою яких буде реалізуватися розумне регулювання: попередня оцінка регуляторного впливу нових проектів актів законодавства; визначення та зменшення адміністративного тягаря; спрощення чинного законодавства та регулювання, включаючи їх консолідацію та кодифікацію; проведення консультації громадськістю та зацікавленими акторами; оцінка фактичного впливу регуляторних актів; полегшення доступу до законодавчої бази.

У 2010 році згідно із Меморандумом Свропейської Комісії «розумне регулювання» мало за мету максимальне підвищення якості законодавчого забезпечення відповідно до принципів субсидіарності і пропорційності за трьома напрямами [3]:

1. Комплексний підхід на усіх етапах державно-управлінського циклу: від підготовки нормативно-правових актів, прийняття рішень, до ретроспективного спрощення діючого законодавства з акцентом на оцінці чинного законодавства і політики.

2. Посилення спільної відповідальності усіх органів, залучених до регуляторного процесу: Європейського парламенту, Європейської Ради, держав-членів та інших зацікавлених сторін.

3. Підвищення ролі громадян та зацікавлених сторін шляхом продовження строків публічного обговорення проектів у рамках циклу прийняття рішень із 8 до 12 тижнів, переглядом політики Єврокомісії щодо консультування з громадськістю та збільшення прогнозованості пропозицій Єврокомісії та оцінки поточної політики, що дасть змогу зацікавленим сторонам приєднатися до нормотворчого процесу на ранніх етапах.

Однак згодом від вживання терміну «розумне» регулювання, повернувшись до «кращого регулювання». У 2015 році Єврокомісія поставила перед собою низку амбітних завдань щодо покращення регуляторної політики.

1) Покращити участь зацікавлених сторін через: посилення зворотного зв'язку протягом усього життєвого циклу прийняття рішень, включаючи законопроекти 3 делегування та виконання рішень; б) продовжити термін консультацій до 12 тижнів для усіх нових пропозицій та оцінок, в) створення нового веб-порталу, де всі зацікавлені сторони можуть отримати інформацію про нові ініціативи Сврокомісії та висловити свою думку;

2) інтегровані керівництва та повний набір інструментів для працівників Сврокомісії про те, як застосовувати краще регулювання на всіх етапах розробки і прийняття рішень;

3) оцінювати чинне законодавство до висунення поправок до нього («спершу оцінка»);

4) незалежна Рада з регуляторної експертизи розглядає якість усіх оцінок впливу та основні оцінки, складаючись 37 чиновників на повну ставку, які не залучені до процесу прийняття рішень, включаючи трьох зовнішніх експертів з-поза органів СС;

5) систематично перевіряти можливості для спрощення та більшої ефективності при перегляді чинного законодавства без шкоди його цілям;

6) створити платформу REFIT для підтримки зусиль Сврокомісії щодо спрощення регуляторного законодавства 
В 2019 році був опублікований звіт роботи Єврокомісії [4] під керівництвом Ж.-К. Юнкера, згідно з яким за 2015-2018 роки їй вдалося досягнути певного успіху у реалізації цих завдань, найбільш помітний він у публікації намірів або дорожніх карт (документ, в якому описується проблема, на вирішення якої спрямований законопроект та можливі варіанти політики Союзу у цій сфері) для отримання реакції з боку зацікавлених сторін (691 документ), проведенні консультацій з громадськістю (417 заходів), проведення оцінки (259 випадків), оцінка впливу (218 документів), публікації законопроектів щодо делегування повноважень для встановлення зворотного зв'язку із зацікавленими сторонами (151 документ), заходи щодо спрощення законодавства (150 документів), обговорення законопроектів на платформі REFIT (89 документів).

Однак для ефективної регулятивної політики значення має не лише нормативно-правове забезпечення, а й органи, які будуть їі реалізовувати. Ще в кінці XX ст. важливість інститутів в обговоренні і розробці державної політики значною мірою ігнорувалася, хоча жодна політика не може дати очікуваних результатів, якщо відсутні інститути, які забезпечують правильне застосування регуляторних актів.

У найбільш загальному вигляді регуляторні інститути можна звести до регуляторних наглядових органів і незалежних регуляторних організацій. Зазвичай наглядові органи за регуляторною політикою входять до складу центрального органу виконавчої влади, оскільки є важливим регуляторним інститутом, що підвищує якість регуляторного процесу і сприяють постійному їі удосконаленню. Їх основне завдання - здійснювати нагляд, координувати, оскаржувати питання та надавати консультації регуляторним органам, сприяння законодавчим реформам, підвищення якості регуляторного процесу і досягнення певних вигід.

Вони мають бути наділені відповідними повноваженнями та можливість координувати i підтримувати загальнодержавний підхід, отримувати певну вигоду від постійного мандату. Хоча більшість таких органів входять до системи органів державної влади, вони також можуть бути представлені різноманітними консультаційними комісіями, парламентськими та міжурядовими комітетами. Їх основне завдання полягає у координації і нагляді, забезпеченні відповідності певним стандартам якості реформ регуляторної політики. У свою чергу функція оскарження дає наглядовому органу повноваження піддавати сумнів доцільність прийняття регуляторного акту завдяки оцінці якості регуляторної політики за допомогою Аналізу регуляторного впливу (APB) та можливості накласти вето на регуляторний акт, що не відповідає вимогам якості.

Можливості наглядових органів щодо впливу на якість регулювання зводяться до наступного: здатність координувати інституційні структури в загальнодержавній перспективі, незалежність і достатній обсяг повноважень, політична підтримка на вищому політичному рівні. Необхідним також є існування незалежних регуляторних органів, які не залежать від політичної системи і яким передаються повноваження з реалізації окремих політик у низці секторів економіки (зазвичай у сфері комунального обслуговування (енергетика, зв'язок) або у секторах, в яких необхідний пруденційний нагляд).

Основна перевага таких органів полягає у тому, що вони убезпечують ринкові інтервенції від політичних та приватних інтересів, що закладає основи для покращення регуляторної ефективності, розділення ролі держави як директивного органу та власника виробничих ресурсів. Їх діяльність має визначатися відповідним законом, в якому чітко прописані їх функції, цілі та повноваження. При цьому незалежні регуляторні органи створюють певні проблеми для органів виконавчої та законодавчої влади. Основна полягає у тому, що вони не обираються напряму громадянами і не керуються виборними особами, оскільки вони створюються урядом і наділяються повноваженнями діяти незалежно від виборних органів держави.

Відповідно виникає питання, яким чином буде здійснюватися контроль за реалізацією ними регуляторних повноважень, а також висловлюються побоювання утворення «держави в мініатюрі», що веде до ерозії принципу поділу влади. Також слід визнати, що незалежні регуляторні органи завжди до певної міри залежатимуть від політичної ситуації в країни, оскільки змушені 
діяти у рамках, що визначаються законом і адміністративними структурами, які можуть бути безпосередньо змінені парламентом і судами, а опосередковано-органами виконавчої влади. Тому ефективні регуляторні органи повинні враховувати довгостроковий політичний курс, що зрештою легітимізує їх існування.

Серед недоліків незалежних регуляторних органів слід згадати і регуляторне захоплення [5], зниження у довгостроковій перспективі регуляторної якості в інфраструктурних секторах: сповільнення структурних змін, втрата потенційних доходів для споживачів. До того ж регуляторні органи часто створюються за секторальною ознакою, що утруднює конвергенцію між секторами і перешкоджає утворенню нових бізнес-моделей, може призвести до фрагментації державної політики і заходів, особливо щодо політики конкуренції. Мінімізувати ці ризики можна шляхом чіткого визначення ролі регуляторних органів та посилення механізмів їх підзвітності.

Недержавні регуляторні органи можна класифікувати на чотири групи: 1) відомчі департаменти (агентства, що є частиною центрального уряду і не мають статусу окремого корпоративного органу, належать до державної служби і напряму підпорядковані міністру)

2) відомчі агентства, які не залежать від органів центральної виконавчої влади, можуть мати і власний бюджет, відокремлене керівництво, але перебувають у підпорядкуванні міністерства і під його оперативним керівництвом);

3) незалежні консультативні органи - агентства, наділені повноваженнями давати уряду, парламенту та приватним організаціям офіційні експертні рекомендації щодо окремих регуляторних актів та промислового сектора.

4) незалежні регуляторні органи - агентства, на які покладено відповідальність за здійснення регулювання окремих аспектів промислового сектора. Мають незалежне керівництво, але їх бюджет затверджується відповідним міністерством. При цьому сфера політичного чи відомчого втручання у діяльність органу не визначена або ж обмежується наданням консультацій із загальнополітичних, а не вузькоспеціалізованих питань.

Для більш ефективної роботи незалежних регуляторних органів строки призначення їх керівництва повинні перекривати виборчі або політичні цикли, що посилює їх незалежність. Крім того, вони повинні бути забезпечені достатніми фінансовими ресурсами для реалізації свого мандату, але механізми фінансування не повинні впливати на їх незалежність. Це досягається через пряме стягнення зборів з осіб, що підпадають під регулювання, централізованого фінансування з держбюджету,

Інституційні органи регуляторного нагляду в СС представлені: 1) Генеральним секретаріатом Єврокомісії, який відповідає за узгодженість роботи комісії, наглядає за реалізацією програми «Краще регулювання». Він також виконує функції секретаріату для Ради з регуляторної експертизи, що перевіряє якість усіх оцінок законодавчого впливу та основних висновків. Ця рада складається з трьох чиновників Комісії та трьох зовнішніх експертів, а очолюється Генеральним директором Єврокомісії; 2) Директоратом з оцінки впливу Європейського парламенту, який також проводить оцінку законопроектів, поданих Сврокомісією, а також може проводити глибший аналіз та давати оцінку впливу законодавчих поправок на вимогу комітетів Європарламенту; 3) Європейським судом аудиторів, найвищим аудиторським інститутом ЄС, що теж може здійснювати аудит результатів діяльності системи регуляторного управління.

Попередником Ради з регуляторної експертизи була Рада 3 питань оцінки впливу регуляторних актів (РОВРА), створена у 2006 році-центральний орган, який забезпечує проведення експертизи законопроектів, підготовлених Єврокомісією, збирає та аналізує усі думки щодо оцінки їх потенційного впливу на відповідні сфери. Позитивна резолюція РОВРА необхідна для розгляду усіх проектів, які подаються на розгляд СК. А висновки РОВРА про потенційний вплив нових актів законодавства супроводжують законопроектну ініціативу на всіх етапах прийняття рішень Єврокомісією. У випадку прийняття певної ініціативи звіт по ній РОВРА про оцінку його потенційного впливу оприлюднюється, що дає змогу приватним і громадським 
організаціям отримати інформацію щодо очікуваних результатів та ризиків його імплементації. При цьому Рада наділена певною автономією і не залежить від структурних підрозділів ЄК, які займаються розробкою регуляторних актів для відповідних сфер економіки та соціального життя СС.

\section{Висновки}

Отже, з огляду на проголошений курс на євроінтеграцію, Україні слід адаптувати свою регуляторну політику відповідно до сучасних підходів Євросоюзу. Як свідчать дані урядового порталу про стан виконання Угоди про асоціацію між Україною та Євросоюзом «Пульс угоди» прогрес у цій сфері неоднозначний: у низці сфер вимоги виконані майже на $75 \%$ (технічні бар'єри у торгівлі; юстиція, свобода, безпека, права людини; підприємництво), а в інших лише близько $20 \%$ (інтелектуальна власність; фінансовий сектор; транспорт, транспортна інфраструктура). Також досвід ЄС засвідчив необхідність належного інституційного забезпечення такої політики, яка повинна основний акцент робити на максимально ранніх етапах процесу прийняття нормативно-правових актів: публікувати наміри органів державної влади щодо змін у законодавстві та ретельно відстежувати відповідність чинного законодавства потребам суспільства. На сьогодні основним органом у цій сфері є Державна регуляторна служба України, однак непрозорість процедур формування керівництва низки інших органів та їх залежність від політичного процесу, зокрема Національної комісії, що здійснює державне регулювання у сфері енергетики та комунальних послуг (НКРЕКП), зумовлює низький рівень до них серед громадян. Тому один із напрямів регуляторної реформи в Україні має мінімізувати й такі недоліки незалежних регуляторних органів як можливе зниження регуляторної якості в інфраструктурних секторах, створення за секторальною ознакою.

\section{REFERENCES:} $77-101$.

1. Majone, G. (1994). The rise of the regulatory state in Europe. West European Politics, 17 (3),

2. OECD (2002), Regulatory Policies in OECD Countries. From Interventionism to Regulatory Governance, Paris. Available at: https://www. oecd. org/gov/regulatory-policy/41882845.pdf (Accessed: 15 November 2019).

3. Smart regulation: ensuring that European laws benefit people and businesses. Available at: https://ec. europa. eu/commission/presscorner/detail/en/IP_10_1296 (Accessed: 15 November 2019).

4. Better regulation: taking stock and sustaining our commitment. 15 April 2019. Available at: https://ec. europa. eu/info/sites/info/files/better-regulation-taking-stock_en_0.pdf (Accessed: 15 November 2019).

5. Laffont, J.-J. and Tirole, J. (1991), The Politics of Government Decision-Making: A Theory of Regulatory Capture, The Quarterly Journal of Economics, 106(4), 1089-127. 